Meta

Journal des traducteurs

Translators' Journal

\title{
The Missing Style Problem and the Translation of French Erotica into English
}

\section{Brian Mossop}

Volume 62, numéro 2, août 2017

URI : https://id.erudit.org/iderudit/1041027ar

DOI : https://doi.org/10.7202/1041027ar

Aller au sommaire du numéro

Éditeur(s)

Les Presses de l’Université de Montréal

ISSN

0026-0452 (imprimé)

1492-1421 (numérique)

Découvrir la revue

Citer cet article

Mossop, B. (2017). The Missing Style Problem and the Translation of French Erotica into English. Meta, 62(2), 333-349. https://doi.org/10.7202/1041027ar
Résumé de l'article

Dans la plupart des ensembles synonymiques, il y a une expression neutre, qui n'appartient à aucun style (pauvre est neutre tandis qu'indigent et fauché ne le sont pas). Pour le domaine des écrits érotiques, le français possède un style neutre, mais un style semblable manque en anglais. Les traductions anglaises de deux autobiographies françaises, dont les auteurs décrivent en détail leur vie sexuelle, sont présentées et certaines stratégies des traducteurs sont mises en relief. Ces écrits érotiques sont considérés dans le cadre plus général des options stylistiques disponibles en traduction. On peut théoriser le travail stylistique du traducteur d'au moins deux façons : ou bien par comparaison avec le texte de départ (employer un style équivalent ou un style existant différent, créer un style nouveau, avoir recours à un 'style de traducteur par défaut') ou bien par la façon de prêter une 'voix' au texte en langue d'arrivée (utiliser la voix du texte de départ, la voix imaginée des futurs lecteurs, la voix du traducteur lui-même, ou encore une voix autre).
Ce document est protégé par la loi sur le droit d'auteur. L’utilisation des services d’Érudit (y compris la reproduction) est assujettie à sa politique d'utilisation que vous pouvez consulter en ligne.

https://apropos.erudit.org/fr/usagers/politique-dutilisation/ 


\title{
The Missing Style Problem and the Translation of French Erotica into English
}

\author{
BRIAN MOSSOP \\ York University, Toronto, Canada \\ brmossop@yorku.ca
}

\begin{abstract}
In most synonym sets, there is a neutral item that does not belong to any particular style (poor is neutral whereas impecunious and broke are not). In writings about sex, French has a neutral style but English does not. The English translations of two French autobiographies detailing the authors' sex lives are presented and some of the translators' strategies are discussed. These two cases are seen against the general background of style options available to translators. A translator's approach to style can be theorized by comparison to the source text (use an equivalent style, use a different existing style, create a new style, use a default 'translating style') or by considering how the translator 'voices' the translation (use the voice of the source writer, the imagined future readers, the translator, or some other voice).
\end{abstract}

\section{RÉSUMÉ}

Dans la plupart des ensembles synonymiques, il y a une expression neutre, qui n'appartient à aucun style (pauvre est neutre tandis qu'indigent et fauché ne le sont pas). Pour le domaine des écrits érotiques, le français possède un style neutre, mais un style semblable manque en anglais. Les traductions anglaises de deux autobiographies françaises, dont les auteurs décrivent en détail leur vie sexuelle, sont présentées et certaines stratégies des traducteurs sont mises en relief. Ces écrits érotiques sont considérés dans le cadre plus général des options stylistiques disponibles en traduction. On peut théoriser le travail stylistique du traducteur d'au moins deux façons: ou bien par comparaison avec le texte de départ (employer un style équivalent ou un style existant différent, créer un style nouveau, avoir recours à un 'style de traducteur par défaut') ou bien par la façon de prêter une 'voix' au texte en langue d'arrivée (utiliser la voix du texte de départ, la voix imaginée des futurs lecteurs, la voix du traducteur lui-même, ou encore une voix autre).

\section{RESUMEN}

En la mayoría de conjuntos de sinónimos, existe un elemento neutral que no pertenece a ningún estilo en particular (pobre es neutral, mientras que indigente y arruinado no lo son). Al escribir sobre sexo, el francés tiene un estilo neutral que el inglés no tiene. Se presenta la traducción al inglés de dos autobiografías francesas que describen la vida sexual de los autores y se discuten algunas de las estrategias que emplearon los traductores. Se comparan estos dos casos con el contexto general de opciones estilísticas que tienen los traductores a su disposición. Se puede teorizar el enfoque de un traductor con respecto al estilo al comparar la traducción con el texto origen (usa un estilo equivalente, usa un estilo diferente, crea un estilo nuevo, usa un "estilo de traducción" estándar, etc.) o al considerar cómo el traductor "da una voz" a la traducción (emplea la voz de quien produjo el texto, la voz de los lectores futuros, la propia voz del traductor u otra voz).

\section{MOTS-CLÉS/KEYWORDS/PALABRAS CLAVE}

style, registre, stratégies de traduction, niveau de langue, érotisme, voix style, register, translation strategies, level of language, erotica, voice estilo, registro, estrategias de traducción, nivel lingüístico, erotismo, voz 


\section{The Neutral style}

Style is a matter of choosing among alternate wordings. Within a domain of writing, a range of styles will be available in the form of lexical, phraseological, syntactic and rhetorical (suprasentential) choices. With respect to the lexicon and phraseology, each member of a synonym set can generally be assigned to some style. For example, in writings about the domain of poverty, we might find the following styles:

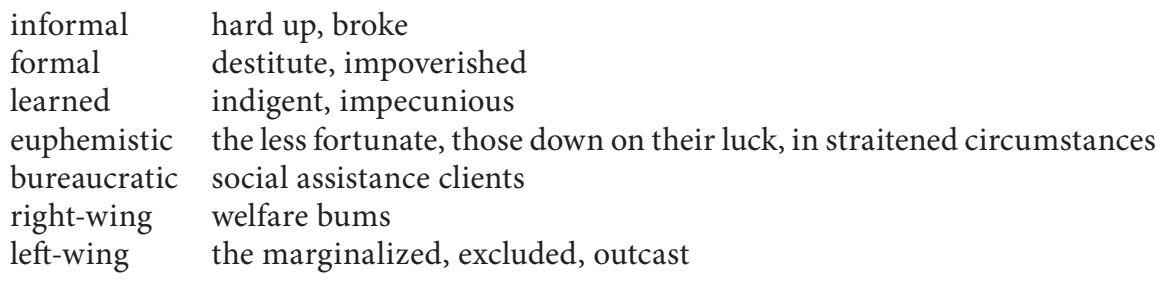

In this article, 'style' does not refer to the full set of linguistic choices characteristic of an individual text, an author's (or translator's) work in general, or a given genre or time period. Instead I use it in a restricted sense somewhat similar to that of 'register' in linguistics. The Concise Oxford Dictionary of Linguistics ( $2^{\text {nd }}$ edition 2007) defines 'register' as "a set of features of speech or writing characteristic of a particular type of linguistic activity or a particular group when engaging in it." Of course, which linguistic features are 'characteristic' of an activity may be debatable. Certainly, translators sometimes find it not at all obvious which style of the target language is the appropriate one. Also, 'register' frequently implies unconscious switching from one style to another when the situation changes, thus eliminating from consideration both conscious, motivated style choices and random variations in style within a single situation. In view of these drawbacks of the term 'register,' I will simply use 'style' to refer to the sorts of choices exemplified above.

Although translators and translation scholars frequently mention style, there is no generally accepted approach to the matter in relation to translation (Munday 2008: 29-30), or terminology for discussing it. There is a vast body of theoretical writing on style in sociolinguistics and in literary studies, but in English-language translation theory there is relatively little: the application of Hallidayan register analysis to translation (House 1997); Malmkjaer's proposal of a 'translational stylistics' that seeks ideologically significant patterns in the observable differences between the style features of the source and those of the translation (Malmkjaer 2004: 19-20); Baker's focus on a translator's distinctive target-language style rather than comparison of source and translation styles (2000). ${ }^{1}$ Apart from that, what exists are descriptions of the style of particular (almost always literary) translations or translators, and frequent references to the problem of style matching across languages and the choice between style equivalence and style shift. I draw on this latter tradition in section 2, but attempt something different by way of theory in section 6 . For a discussion of the term 'level of language,' often used by translators to refer to one aspect of style, see Appendix 1.

There is no need for present purposes to devise a system of style differentiators valid for all domains (in the above list of poverty-related expressions, the first two styles are degrees of formality, while the last two concern the political viewpoint of the writer). Nor is there a need to decide precisely how many styles there are for a given domain. That is because the focus here lies elsewhere: I shall be concerned with the fact that most synonyms sets, including the one above, have a further member: 
neutral

poor

The word poor is neutral in the sense that its style can be characterized only negatively, as not bureaucratic, not right-wing, not left-wing, not informal or formal, not learned and not euphemistic.

In this article, I shall be looking at a domain where English lacks a neutral style, namely writing about sex. Now, individual lexical, grammatical or rhetorical 'gaps' in the target language are frequently mentioned as translation problems (English does not have an impersonal pronoun that functions like French on or German man; writers in a language may not be using free indirect speech when a novel featuring this device is translated into it). However, here I shall be considering something quite different: an entire missing style within a domain of writing. To that end, I shall discuss the English translation of two French autobiographical accounts of the authors' sex lives, in sections 4 and 5. In preparation for that discussion, section 2 looks in a general way at the translator's style options, and section 3 at the available English vocabulary for describing sexual activities.

\section{The translator's style options}

Translators have several options, depending on the style ranges available in the two languages for the domain in question. The four logical possibilities, stated in terms of the relationship between source and translation, are:

a) Use a target-language style which the translator has identified as equivalent to the source-language style;

b) Even if the translator thinks an equivalent style exists, deliberately use a nonequivalent style;

c) If the translator cannot identify an equivalent style, choose one of the existing non-equivalent styles;

d) If the translator cannot identify an equivalent style, create a new style.

I leave aside the further possibility that a translator may not give much thought to style, perhaps because he or she needs to produce a translation quickly or is just not a very good translator.

Before considering options a) and c) in connection with the translation of sex writing, let us look briefly at options b) and d). Option b) is famously the approach used by Freud's first English translators, James and Alix Strachey, in the early twentieth century (Ornston 1985). Freud's own style avoided words of Greek and Latin origin, but the translators replaced this style, which could easily have been imitated in English (option a), with a scientific style featuring a heavy dose of Greco-Latin vocabulary, perhaps because they thought Freud's views relating human psychology to sexual and other bodily functions would be more palatable in the English-speaking world if presented in language associated with natural science. So, for example, the non-Greco-Latin and non-scientific German word Mutterleib was rendered by the anatomical term uterus rather than the more everyday word womb.

An interesting variant of option b), to be discussed in section 6, has the translator simply writing in one of his or her own personal styles.

Turning to option d), the creation of a new style through translation is well known in literary history: the translator's work becomes a model for original writing 
in the target language (Even-Zohar 1990/2000: 208). In addition, a new style may be created not deliberately but by accident, as a by-product of certain situations involving translation. For example, English-speaking civil servants in the Brussels bureaucracy, an environment that at one time operated mostly in French, now tend to write English documents in a way that was originally overly literal translation of French, or imitation of French bureaucratese - a habit no doubt reinforced by the fact that they are living in a French-speaking city. This new style has features of French rhetoric and uses English words in the meanings of their French cognates (the 'false friends' phenomenon) (Gardner 2013).

New styles also arise from the common habit of translating prestigious writings in a highly literal fashion (whether this be deliberate, or simply a manifestation of poor translation ability or deficient knowledge of the source language). Translation from French to English seems to have played a role in the origin of a style of humanities and social science writing that did not exist in English before 1980. Consider this selection of sentences from an article in a Translation Studies journal (Radhakrishnan 2005):

The task of the translator enfranchises erotic loving as a form of intransitive passion even as it gestures substantively towards possibilities of a transitive recuperation of intentional commitments and oaths of adequation and loyalty.

Intelligibility without translatability would be invalid, and yet, the ethic of a good translation is to resist and problematize intelligibility.

It is in art and in the theoretical considerations of art that the human recognizes itself in difference, in perennial alterity.

In the very act of translating well and readably, I wanted to achieve two theoretical effects: 1) the effect of a fundamental and incorrigible untranslatability to be valorized in the name of the minor languages, ...

It becomes possible to initially enable polylogues between deconstructive linguistic ventures and emerging linguistic endeavors (always keeping in mind the reality of an unevenness hatched in dominance that I have addressed earlier on in this essay), and eventually imagine a decentered world of relational plays and possibilities.

I may belong to Tamil filiatively and to English affiliatively; but in any case, I am doubly interpellated, ...

Situated between two languages and loving both differently, I still had to be aware that the onus of intelligibility falls differently on Tamil and English, not for intrinsic philosophical reasons, but only because we live in a world structured in dominance where English is a canonically desirable world language whereas Tamil is not.

Or to put it differently, in the context of Foucault's discussion of "verbality" in 'The Order of Things,' how is the priori of language distributed between a primordial intelligibility secured as translatability, and an intelligibility of the progressive tense to be embodied in the specificity of actual translations?

Looking only at vocabulary rather than sentence structure or rhetorical devices, we see here words, or senses of words, that had been rare or non-existent before 1980: valorized, decentered, problematize, alterity, recuperation, adequation, interpellate, primordial, and the phrase structured in dominance. These usages were probably first introduced into English in two ways: first, through rather poor translations of French poststructuralist writings in the late 1970s, the style of which was then imitated in 
original English writing; second, through the work of scholars who read the original French and then, in their own writing, imitated French rhetoric and used English cognates of French words such as problématiser, interpeler and valoriser. The obscure, indeed nonsensical phrase structure in dominance was introduced to express Louis Althusser's very clear notion of a structure à dominante (structure that has a dominant element, dominante being an abbreviation of instance dominante)- the idea that some element of social structure, such as the church under feudalism, plays a dominant role. The English preposition 'in' completely fails to convey the relationship between 'structure' and 'dominance.'

The newly created style illustrated above served to distinguish postmodern scholars from 'old-fashioned' humanities scholars. Note that it is definitely not 'neutral' in the sense previously mentioned. New styles, whether introduced deliberately or accidentally, are never neutral in the target-language setting. This is presumably true in any language: wordings introduced through translation inevitably impress target-language readers as novel and therefore cannot be received as neutral.

\section{The sex vocabulary of English}

The sex-related vocabulary of English can be described as falling into three groups. Group 1 contains the words whose principal or sole meaning has to do with body parts or bodily motions commonly involved in sex acts: tits, penis, fuck, ejaculate and so on. Group 2 is made up of words having a common metaphorical meaning that is used in sex discourse, such as pussy and screw. Group 3 words (such as breast and kiss) occur in sex discourse but more commonly occur in other kinds of discourse (die of breast cancer, kiss a child goodbye). Many Group 3 words are neutral, and they can certainly be used in describing a sexual encounter (She kissed Lila's breasts); however, there are not enough of them to enable a detailed description.

As a first approximation, sufficient for present purposes, let us say that the core English sex vocabulary - words of Groups 1 and 2 - makes five styles available:

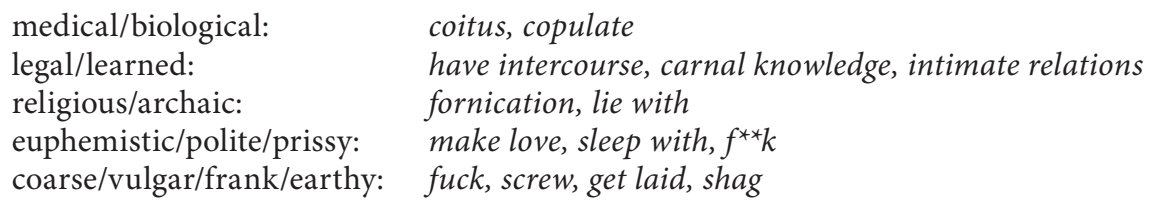

The details of this list are not important: some might want to recognize degrees within a style (fuck is coarser than get laid), or separate a 'religious' from an 'archaic' style, or add a 'humorous' style (horizontal mambo). However, my purpose here is not to report the results of a detailed comparison of the sex vocabularies of French and English. ${ }^{2}$ I shall be discussing style in textual rather than lexicographical terms; specifically, I shall be looking at a few of the English wordings which the translators of our two autobiographies chose, and considering what they did about the problem of a missing neutral style in the target language.

I shall ignore the distinction between speech and writing. The coarse style is no doubt used much less in written than in spoken English, but that difference is not relevant here since the coarse style is used very extensively in the two translations to be considered. 
Discussion will focus on lexical choice, with just two mentions of a grammatical feature and no discussion of sentence structure or rhetorical devices. As a result, I do not ask whether the impression of neutrality one gets in reading these French texts arises just as much or even more from syntax and rhetoric as it does from vocabulary. Still, since I am discussing the work of translators, who are not engaging in a word replacement exercise but rather in the creation of running text, the syntagmatic dimension will be briefly acknowledged, in terms of the relationship among the lexical choices made within a sentence or a passage.

Studies of erotica/pornography ${ }^{3}$ translations often focus on the need to 'tone down' the sexual content of the source text because of censorship in target-language countries or general cultural attitudes toward sex. While one of the translations to be discussed does contain some cases of omission of sex-related vocabulary, there is no generalized 'toning down. ${ }^{4}$ As a result, it is possible to look at these translators' lexical choices by reference to facts about the English language as such, without there being a suspicion that the choices are being covertly governed by cultural attitudes in the country of publication (though they may be governed, perhaps unconsciously, by the translator's own attitude to sex and sex-related language, a topic I shall not consider for lack of evidence). That said, it is no doubt true that social attitudes toward sex do wash over onto language, so that the reaction of an English speaker to reading a coarse English word like prick will not be the same as the reaction of a French speaker to reading a coarse French word like bite, which a translator might well translate by prick. Since translators cannot do anything about this difference (short of omission), and since I am concerned here more with translation production than with reader reception, this matter too will be left out of consideration.

A further issue that bears mention is the ability of a translator (or translation scholar!) to fully grasp the style of the source text when it is written in the translator's or researcher's second language. Unless such a translator has lived for a considerable time in a place where the source language is spoken, the emotional impact of sex talk will probably not register fully. One can know intellectually that a word is 'coarse,' but that is different from feeling the coarseness. A question then arises: does this absence of true emotional impact mislead the translator into perceiving the sex vocabulary of the source language as neutral? The answer is that it might, but this is irrelevant with the two source texts under consideration here because, as we shall see, their authors, as well as the author of the preface to one of the texts, all native speakers of French, tell us (one of them in so many words, the others by clear implication) that French can describe sex neutrally. In other words, the neutrality claim about French is not an error on my part or that of the two English translators (who, as we shall see, both report the possibility of neutrality in French but not in English).

Finally, although I am claiming that English lacks neutral vocabulary to write about sex, it is possible that small groups of English speakers, including perhaps gay men and sex workers when speaking to each other, do treat some of the core English sex vocabulary as neutral. However, I leave this possibility out of consideration since, even if it exists, it is a minor phenomenon and one not manifest in the written language. For a neutral style to appear in English sex writing, there would have to be a cultural change during which young speakers and writers of English re-assess the sexual vocabulary. In the absence of such a change, an English translator of French in this domain has no choice but to omit neutral-style words or switch to a non-neutral style. 


\section{Text 1 - Translating Gay Sex}

In 1979, Renaud Camus published a chronicle entitled (in French) Tricks, ${ }^{5}$ the chapters of which describe in detail sexual encounters between himself and a series of other men over the course of a few months in 1978. Table 1 contains a short passage from the book along with the English translation by Richard Howard: ${ }^{6}$

TABLE 1

\section{A Passage from Camus' Tricks with Howard's English translation}

Nous sommes donc nus, étendus l'un contre l'autre, moi sur lui, les mains sous ses fesses, les caressant, et ses cuisses. ... De nouveau l'embrassant, j'ai passé mon sexe sous ses couilles, et progressivement lui relève les jambes. (L'autre matin, David: - Je vous vois venir, vous, avec vos gros sabots... - Pas du tout! - Dommage...) Une première tentative pour m'introduire en lui, grâce seulement à la salive laissée l'instant d'avant, n'aboutit à rien. ... Nous nous embrassons un peu, les bras autour des épaules, côte à côte. Il se branle. Je me branle. Mais comme ça ne m'amuse pas tellement, je me mets à mon tour de la salive dans le cul, m'agenouille de part et d'autre de lui, et introduis son sexe, qui n'est pas d'une taille très considerable, sans grande difficulté en moi. D'une main, je lui caresse les cuisses derrière moi, ou serre ses fesses contre moi, de l'autre je me branle. Penché en avant, je l'embrasse dans le cou. Cette position m'excite beaucoup. Je jouis sur son ventre. Il ne paraît pas tenir à m'enculer davantage. Je m'allonge de nouveau contre lui. Il se branle. J'ai un bras sous son dos, et d'une main je lui caresse les cuisses, les couilles. Il jouit au moment où l'un de mes doigts est contre la fente de son cul. (Camus 1979/1982: 33)
So now we're naked, stretched out together, me on top of him, my hands under his buttocks, caressing them and his thighs.... Once more, kissing him, I thrust my cock under his balls and gradually raise his legs. (The other morning, David: "I see what you're up to, you're about as subtle as a sledge hammer" "I'm not doing a thing!" "Too bad.") A first attempt to put my cock inside him, with no more help than the saliva left there a moment before, gets nowhere. ...We kiss a little while, arms around each other's shoulders, side by side. He plays with himself. So do I. But since I don't get much out of that, I put some saliva in my ass this time, straddle him, and stick his cock, which isn't big, up my ass without much difficulty. With one hand, I caress his thighs or press his buttocks against me, and with the other I play with myself. Leaning forward, I kiss his neck. This position excites me a lot. I come on his belly. $\mathrm{He}$ doesn't seem to want to fuck me any more. I stretch out beside him again. He plays with himself. I have one arm under his back, and with one hand I caress his thighs, his balls. He comes just when one of my fingers is against his asshole. (Camus/Howard 1982: 6)

The French passage contains no scientific or euphemistic vocabulary. It does contain both neutral and coarse vocabulary, both of which I have bolded along with the corresponding wordings in the English translation. (In speaking of a neutral style, I do not mean that every lexical choice in a passage is neutral. The neutral style by its nature does not clash with any of the other styles.)

In a translator's note, Howard points out the problem he faced:

It is more difficult to translate French texts dealing with pornographic subjects and low life than anything else. The French have developed a middle language somewhere between the smell of the sewer and the smell of the lamp, which in English is mostly unavailable. We have either the coarse or the very clinical. (1982: 251)

Of the options listed in section 2, Howard usually chose option c), replacing the French neutral style with the English coarse style, which can also be called the frank style. He may have done so in the expectation that most readers in 1982 would be gay men influenced by the then-recent movement for gay liberation. The alternatives under option c) - the scientific or the euphemistic style - would not have appealed 
to this readership. ${ }^{7}$ In the sample passage, one might see play with myself as a euphemism, replacing the coarse jerk off, but Howard may have seen it instead as what I am calling a Group 3 neutral expression.

The French word sexe, seen twice in the above passage, is a neutral word for genitals; its definition in the Robert dictionary reads: "parties sexuelles; organes génitaux externes (de l'homme ou de la femme)." When used for the penis alone, it has none of the coarse, scientific or euphemistic force of English dick, prick, penis, member, organ, phallus, shaft, rod or cock, the last of these being the coarse-style word which Howard regularly chooses to translate sexe. According to the Oxford Dictionary, the word sex has occasionally been used in the meaning 'genitals,' from the seventeenth century to the present, but the dictionary marks this sense as 'slang or euphemistic,' and at any rate it is not at all common. If the wording I thrust my sex under his balls...were used, sex could well be taken by readers as a euphemism and this would clash with balls, which is (mildly) coarse.

Turning now to the phrase m'introduire en lui, this is a neutral description of what happened; it has a very different effect from Howard's translation put my cock inside him. Cock is not a neutral word, and there is no neutral word Howard could have chosen. Are any other English wordings available? Certainly not the Group 3 word introduce: writing introduce myself would be a case of turning neutral French into humorous English. What about enter him? Here a problem would arise at the intersection of language and culture: prevailing attitudes toward sex in Englishspeaking cultures would probably come into play and readers might well take enter as a euphemism rather than a neutral Group 3 word. Slippages to a euphemistic or humorous reading are a possibility with any word that has a sufficiently broad meaning, as do enter and introduce. A similar problem would arise with the phrases get it in or put it in: apart from the fact that the antecedent of it would not be immediately clear, it also seems to be a way of avoiding cock or some other coarse word.

Camus' use of a neutral linguistic style perhaps reflects the neutrality of the book in the sense set out in the Preface by Roland Barthes:

Renaud Camus' Tricks are simple. This means that they speak homosexuality, but never speak about it... [His] narratives are neutral; they do not participate in the game of interpretation. They are surfaces without shadows, without ulterior motives. ...If it weren't for their extent and their subject, these tricks might suggest haikus, for the haiku combines an asceticism of form.... and a hedonism so serene that all we can say about pleasure is that it is there (which is also the contrary of interpretation) (1982: viii, italics in original)

Neither the narrating voice nor the two sex partners ever comment on ("interpret") homosexuality: not during the pick-up at a dance club, the trip home, the after-sex conversation or the parting.

In his Foreword, Camus describes the book as neutral in yet another sense when he tells us what it is not:

This is not a pornographic book... This is not an erotic book...or an attempt to titillate the reader. This is not a scientific book...not even a sociological document. ...This book attempts to utter sexuality, in this instance homosexuality,... calmly. (1982: xi)

The phrase "utter sexuality...calmly" is important. The tone of Camus' sex narrations is always observational, even though the observer is also the chief participant. Both 
Barthes and Camus are talking about discourse when they use the words "calmly" and "neutral"; they are certainly not talking about actual sexual activity, or feelings about it. Sex, after all, is a subject about which human beings are rarely calm and neutral! But acts that are not neutral can be "uttered" using neutral language - or at least they can in French.

\section{Text 2 - Translating Straight Sex}

In art critic Catherine Millet's memoirs La vie sexuelle de Catherine M., ${ }^{8}$ she describes her sexual encounters with a large number of men over several decades. Even though she keeps shifting from biographical details about herself to sociological or philosophical commentary to narrations of sex activities, she manages to maintain a consistent tone typical of what may be described as 'high literary French.' Like Camus, Millet manages to write about sex both elegantly and explicitly yet without being crude or judgmental, and the voice she creates is similarly serene and observational. A comment by Hartlen (2006: 68) about verbs such as branler [masturbate/jerk off] and sucer [suck] in a passage of the Camus book could equally apply to Millet's writing: "The verbs....are neutral and natural, free of either the hyperbole of conventional pornography or the euphemisms of other (supposedly literary) erotic writing."

The French text was published by the prestigious mainstream house Seuil, but the English translation by Adriana Hunter ${ }^{9}$ was published in the U.S. by Grove Press, which has a history of publishing books considered risque in their time, such as Lawrence's Lady Chatterley's Lover and Burroughs' Naked Lunch. In the UK, the translation was published by Serpent's Tail, which specializes in translations of transgressive writing. The identity of the English-language publisher suggests an expectation that the translation might well be received as non-literary pornography, especially in view of source-country stereotypes:

The French can intellectualize anything - food and drink, football, being and nothingness. Pornography must have been a challenge, but Catherine $M$ has risen to it in a way that will have Descartes encoring from Beyond. (Ron Butlin in Sunday Herald, 2 June 2002, cited by Rao and Klimkiewicz 2012: 238)

Such reception would be less likely with the source text, not only for cultural reasons, or because the author is well known in France as an art critic, but also because a neutral, observational style is available in French.

The issue of the neutral style arose in interviews with Millet and her translator at the time of publication:

Le mot sexe en français est un mot neutre: si je dis "il se déshabille et je vois son sexe," ce n'est qu'une observation. (Millet cited by Philippe Dagen in Le Monde, 21 February 2002: 32 (http://scholar.lib.vt.edu/Chronicles_Ingest/InterNews_bag/data/InterNews/ LeMonde/issues/2002/monde.20020221.pdf))

I had so much trouble with this word, 'le sexe de l'homme.' In French, it's such a perfectly neutral word... It's not sexy, or dirty, and it's not scientific either, like 'penis.' (Hunter cited by Kristen Hinman, Paris Voice, May 2002 (www.parisvoice.com/archives))

Like Howard, Hunter must often resort to a style different from the one used in French. However, her approach differs from Howard's in that one of her common choices, as Santaemilia points out (2009: 134), is omission: sucer le sexe des hommes 
[suck men's sexe] becomes sucking a man off. She also uses omission with other French words referring to the male organ: c'est à peine si je ressentais bien la pénétration de son membre [I was barely feeling the penetration of his member] becomes $I$ didn't even feel his penetration; chaque poussée de sa verge [every thrust of his rod] becomes every thrust. If a count of such instances were made, presumably it would show that the reader of the translation would encounter far fewer instances of direct naming of the male organ than the reader of the French, though against this, it would of course be necessary to count any instances of explicitation such as the one seen in the Camus passage (m'introduire en lui/put my cock inside him).

Closely related to omission is Hunter's use of vagueness, also pointed out by Santaemilia. Where Millet has the matter-of-fact entrejambe [crotch], Hunter has between his legs; where Millet has the overtly sexual coïts [copulations], Hunter has couplings.

Thus Hunter makes heavy use of Group 3 words: penetration, thrust and couplings are certainly neutral, but then they are not part of the overtly sexual vocabulary of English; the sexual meaning in passages where they are used is deduced by implication from context. Perhaps omission, vagueness and implication are the closest English can come to neutrality in the domain of sex.

Where Hunter does not resort to omission or vagueness, her choices for the neutral word sexe are usually coarse in varying degrees (cock, dick, prick), but sometimes she opts for the scientific style (penis, sexual organ). With other neutral French expressions, Hunter seems ${ }^{10}$ to use a single translation: neutral membre becomes euphemistic/humorous member. ${ }^{11}$ Thus neutral French may become coarse, scientific or euphemistic English. When option a) is available (use an equivalent style in English), Hunter does often draw on it: coarse becomes coarse (baise - fuck), scientific becomes scientific (fellation - fellatio) - though English fellatio is unanglicized Latin and thus further removed from neutral than the gallicized Latin of French fellation.

Hunter's approach results in some rather jarring sequences of lexical choices, as can be seen in the passage on Table 2 (wordings to be discussed below are bolded).

TABLE 2

\section{A Passage from Millet's La Vie sexuelle de Catherine M. with Hunter's English translation}

\begin{tabular}{|l|}
\hline Il faut croire qu'on donne les caresses comme \\
on les reçoit parce que j'ai toujours répondu \\
avec empressement à l'attente des hommes qui \\
étaient eux-mêmes sensibles du cul. J'ai parlé \\
de cet ami qui se présentait lui-même en \\
levrette et que je branlais jusqu'à ce que mon \\
bras et mon épaule se paralysent de douleur. \\
Un autre, sans prévenir, colla un jour ses fesses \\
sur mon nez. C'était au début de notre relation, \\
il se comportait avec pudeur, j'avais dû vaincre \\
ses résistances pour entreprendre une \\
fellation. Mais à peine l'eus-je gobé que, le \\
corps raide, il fit un demi-tour sur lui-même et \\
me présenta, à ma surprise, deux fesses \\
résolues. Il me fut plus facile d'atteindre son \\
trou du cul que son gland. (Millet 2001: 182)
\end{tabular}
It must be that we give caresses in the way that we receive them because I have always responded eagerly to men with sensitive asses. I have mentioned the friend who offered himself on all fours for me to finger-fuck until my arm and shoulder were paralyzed with pain. Another one planted his buttocks on my nose without any warning. At the beginning of our relationship, he was being coy and I had to overcome his resistance before I could undertake fellatio. But I had hardly taken him into my mouth when his body stiffened and he pivoted around and presented me with two resolute buttocks. It was easier for me to get to his asshole than his glans. (Millet/ Hunter 2002: 170) 
Millet's French, like Camus', has a mix of coarse and neutral wordings; since the latter do not clash with the former, a consistent tone is maintained. The translation, however, swings between extremes, coarse language alternating with scientific: fingerfuck... fellatio... asshole... glans. If Hunter had maintained a consistent coarse style, the end of the fourth sentence might have read: ...overcome his resistance before I could suck him off; and the end of the fifth sentence might have read easier for me to get to his asshole than the head of his dick.

In addition, the expression entreprendre une fellation exemplifies the commonplace French phrase structure consisting of a verb of rather vague meaning followed by a noun which carries the main meaning. Translating this structure with parallel English (undertake fellatio) increases formality; to achieve formality equivalent to the French, a verb alone would be needed (before I could fellate him). On the subject of grammar, it should be mentioned in passing that Millet's observational tone is bolstered by the use of two special past tenses, known as the simple past (colla; fit; fut) and the anterior past, a kind of pluperfect (eus gobé). These tenses are not used in spoken French, only in the written language, and then only in literary writing, and not even in all of that (Renaud Camus does not use them in Tricks). Their effect is to create formality, distance and elegance. Since English has no such tenses, their effect cannot be captured when translating the verbs. In the sample passage, a small degree of formality might have been achieved in the second last sentence by imitating the French inverted word order and writing hardly had I taken him in my mouth. However, subject-verb inversion (compulsory after negative adverbs like hardly) may impress English-speaking readers as old-fashioned, and the effect would also be somewhat humorous in this sentence because of the incongruity of the subject matter with the tone created by inversion in English (French inversion as such is neither old-fashioned nor humorous).

\section{Another approach to style in translation}

The approach to style choices set out in section 2 requires style matching across languages. This difficulty is avoided if, instead of looking at style in terms of the relationship to the source text (for example, translate the source style by an existing non-equivalent style), we see it in terms of the way the translator gives the translation a 'voice' in a particular passage. In this approach (an early version of which is detailed in Mossop 2007), style is related to the principal parties in a translating situation: the source writer, the future readership, the translator and the commissioner. The translator can project four voices, by:

a) Reflecting: writing in what the translator takes to be 'her' style, that of the source author;

b) Ventriloquizing: writing in 'your' style, the one assumed to be used by the future readers;

c) Defaulting: writing in 'my' style, one of the translator's own styles;

d) Deferring: writing in a style requested by the commissioner.

Before applying these options to our two autobiographies, let's look at some examples from other domains. Suppose some doctor's notes, written in French, mention that the patient a subi une pneumectomie. For the English translation, I might interpret pneumectomie as technical and decide to Reflect that by writing underwent 
pneumectomy. Alternatively, I might decide to orient my translation toward my readership of non-medical people, and write had his lung removed. This would be Ventriloquizing - writing in what I take to be 'your' voice. On the other hand, if the expected readership consisted of medical people, I could Ventriloquize by writing underwent pneumectomy: in that case, Reflecting and Ventriloquizing would yield the same wording.

One way to Ventriloquize, in cases where the audience is not familiar to the translator, is to use the style of similar documents originally written in the target language. If I am translating a text about aircraft accidents for members of the aviation community, I might decide to occasionally use phrasings I have found in relevant documentation. If I then write The aircraft was IFR from Paris to Montreal, I am Ventriloquizing. However I could also express the idea in my own voice, writing perhaps The aircraft was flying under Instrument Flight Rules from Paris to Montreal. This would be Defaulting.

The voices do not match up with the options listed at the beginning of section 2 . Ventriloquizing can yield either an equivalent style or a non-equivalent-but-existing style, depending on how the translator thinks 'you' (the future readers) would write. Reflecting can yield either an equivalent style or a new target-language style. C. K. Scott Moncrieff, in his 1920s translation of Proust, created a novel syntactic style in English to Reflect the author's lengthy sentences featuring multiple embeddings of clauses within clauses - quite different from the long 'stream of consciousness' sentences Joyce was composing for his 1922 novel Ulysses. Reynolds (2004: 127) compares a long sentence in Scott Moncrieff's translation with the 2002 translation by James Grieve, who Ventriloquizes by using syntax that the readers will likely find more familiar.

Turning to the Defaulting style, this could be one of the styles used by a translator in his or her own target-language writing but, more interestingly, it could be a 'translating style' - a way of choosing words which the translator has come to use over time as a fall-back when translating. Sometimes this latter style may be very bland because the translator, being unsure of the precise meaning of the source, and perhaps in a hurry, uses words of very general meaning to translate much more specific source-language words. These general words may well belong to an existing neutral style in the domain of the text. As a result a source passage that is not in a neutral style will be translated in a neutral style. The Defaulting style is the easiest (and therefore fastest) style in which a translator can write, especially when working in a domain with which he or she is unfamiliar. Defaulting corresponds to one way of implementing the second option listed in section 2 (deliberately use a non-equivalent style even if an equivalent is available).

As for the Deferring style - one that is not 'her,' 'your' or 'my' style because the translator defers to the commissioner's wishes - here is an example from the 1991 English translation of the Quebec Civil Code:

401. ...The movable property serving for the use of the household includes only the movable property destined to furnish the family residence...

The expressions destined to and serving for are certainly not in 'my' voice, if the translator is a native speaker of English. Nor are they in 'her' voice: the wordings destiné à and servant à are perfectly ordinary, idiomatic French, and therefore cannot be Reflected by the ostentatiously unidiomatic destined to and serving for. Finally, 
these wordings are not in 'your' voice: even if the readership is thought of as people with legal training, this is not how English legalese is written. It seems (McLintock 2013) that an initial translation of the Civil Code, written in "plain and simple" idiomatic language by two professional translators who were native speakers of English, was revised by French-speaking lawyers who wanted the English to read more like the original $19^{\text {th }}$ century version of the Code and be closer to the French. I would suggest a further underlying motive: to make it clear that the English is a translation. Unlike Canada's federal Parliament, which officially speaks the law simultaneously in two languages, Quebec's legislature officially speaks in French only. The Deferring voice of the English translation reinforces this fact.

Often, of course, wordings that resemble the style of the Civil Code translation may be produced simply because the translator is just not very good, or was being inattentive. Applying stylistic analysis to such translations is pointless.

Turning now to the English translation of the Camus book, how does Richard Howard 'voice' the sex descriptions? When an equivalent is not available because the source is in the neutral style, he may be Ventriloquizing the voices of other gay men: as mentioned in section 4, there is good reason to think that gay men of the early 1980 s were his expected readers. It is also possible that he is simply Defaulting to his own way of writing or speaking about sex as a gay man himself. When an equivalent style is available, Howard could be Reflecting the source, or he could just as well be Ventriloquizing other gay men or Defaulting to his own style, depending on his mindset at the moment of composing: the resulting wording could be the same for any of these three choices.

Now, what of Hunter's translation of Millet? Is she Defaulting to a personal translating style? Answering that question would require an examination of her other translations. Is she Ventriloquizing? Answering that would require knowing who she thought her readers would be. Also, it appears that she was not Ventriloquizing by the above-mentioned method of writing in the style of similar works originally written in the target language: most such 'sex memoirs' by women in English have been written since her translation and may even have been inspired by it (Mitchell 2012: 15-16). Is Hunter Deferring? It is hard to believe that the commissioner played any role in the word choices. Is she then Reflecting? Sometimes it seems so, but often she chooses a non-equivalent style even though an equivalent is available. And in the passages with odd wordings such as the one cited above, it does not seem that she is Reflecting by consciously creating a new style. In the end, one has to consider the possibility that she was translating in a hurry, had no style strategy in mind, or was not paying close attention to lexical style all the time, or not revising for it. For some criticisms of Hunter's translation, see Appendix 2.

\section{Language and literary interpretation}

In this article, I have offered no literary reading of the Millet book, while for the Camus book I simply pointed to the author's stated goal of "uttering homosexuality calmly" and Barthes' comment that Camus avoids interpreting his sex life. Now, it may be thought that the linguistic choices in the French texts are dictated by the literary aims of the two writers, and that the linguistic choices in the translations ought to be seen in the light of the translators' literary understanding (or misunder- 
standing!) of the French source texts. (For such literary analysis of the Millet translation, see Rao and Klimkiewicz 2012: 244-246; 251-253. ${ }^{12}$ ) This objection to a non-literary, purely linguistic analysis may have some merit with regard to the source texts, though even then, the existence of a neutral style in French is an objective linguistic matter that transcends any particular text. With respect to the translations, the objection may not be valid at all: most translators tend to work on a largely linguistic basis, certainly taking immediate context into account as they render each phrase and sentence, but not necessarily choosing words in light of some overall understanding of the text. Translators often assume that the source author was responsible for the literary agenda of a text and the translator's task is of a more narrowly linguistic nature. I suspect this is true of Hunter, perhaps not true of Howard, but I must leave that question in abeyance.

\section{NOTES}

1. Vinay and Darbelnet's 'comparative stylistics' is a rather different matter. The authors compare preferred wordings in the French and English languages rather than in texts and their translations. For example, they note that writers in French prefer the singular for generics, writers in English the plural (l'odeur du poireau/the smell of leeks) (1958: 281). While this could warn us against seeing a change from singular to plural in a translation as an error, it is not a finding in translational stylistics.

2. In an "erotic dictionary of French and English" (Van Hoof 2003), the first half lists and discusses words by topic; for example, 2300 synonyms of coïter [copulate] in dictionaries published between 1752 and 1999. However styles are never mentioned: fuck and make love appear in a single undifferentiated list. Indeed the author seems more interested in similarity than difference: he emphasizes cases where both languages draw on the same metaphor (e.g., labourer/plough), whereas translator Richard Howard suggests (1982: 251) that English has recourse to metaphor in this domain much more often than French. The second half of the dictionary lists all words on all topics alphabetically, but because the book is addressed to a French-speaking readership, the English listing gives the French equivalents of English words while the French listing defines French words in French. In the absence of French-to-English equivalents, the book was not very useful for the purposes of this article. Oddly, the French word sexe, discussed in section 4, is not in any of the lists, though the list of words describing the full set of male genital organs has as its heading le sexe de l'homme complet.

3. Someone once said that the only difference between a book of visual pornography and a book of erotic pictures is that the former costs $\$ 10$, the latter $\$ 100$. It might be of interest to investigate whether and how the difference between cheap and expensive illustrated sex books is reflected in the linguistic style of the accompanying text. A useful distinction can be made between literary and non-literary sex writing. The latter is essentially a sex aid, whether it be called porn or erotica; the former is not. Most reviewers of the Millet book mentioned that it is not at all titillating: "a deliberately unerotic account," writes Jon Henley in The Guardian (29 October 2009); "pas un stimulant sexuel," writes novelist Mario Vargas Llosa in a 2014 edition of the Millet book. I have used the word erotica in the title and keywords of this article to facilitate online searches.

4. Branch (2013) describes an instance of omission which paradoxically enhances erotic effect rather than reducing it. In an English-to-French pseudo-translation, Boris Vian used dots to indicate a steamy sex scene in the (non-existent) English. He inserted a 'translator's footnote' claiming that the passage had to be omitted from the translation because he might be charged with offences against public morals in France (as Vian in fact had been for a previous pseudo-translation). The reader is thus encouraged to imagine erotic goings-on so 'obscene' that they would attract the attention of prosecutors. Whereas dots usually have a 'toning down' effect in erotic writing, Vian's reader is led to imagine an English text in which the exciting sex scene could actually be read.

5. Camus, Renaud (1979/1982): Tricks. Paris: Persona.

CAmus, Renaud (1982): Tricks. (Translated by Richard Howard). New York: Ace Charter.

6. An American poet, critic, and translator of Charles de Gaulle's memoirs, Baudelaire's Flowers of Evil, Foucault's Madness and Civilization, and many other notable works. Howard translated the original 1979 version of the French. In 1982 and 1988, Camus added several chapters. 
7. On the reception of the two books in the French and English-speaking worlds, see Mossop (forthcoming), where I look at the cover art chosen by the publishers for the source texts and the translations.

8. Millet, Catherine (2001): La vie sexuelle de Catherine M. Paris: Seuil. Millet, Catherine (2002): The Sexual Life of Catherine M. (Translated by Adriana Hunter). New York: Grove Press.

9. British translator, winner of the 2011 Scott-Moncrieff prize for her translation of a French novel. Of the two texts discussed here, the one by a woman was translated by a woman (sexual orientation unknown), and the one by a gay man was translated by a gay man. It might be of interest to compare these with cases where the translator of sex writing differs in gender and/or sexual orientation from the source writer.

10. Since I had access to an electronic version of the English but not of the French, it was not practical to make searches leading to statements of the form 'French $w$ is always translated by English x' or 'by English x, y or z.' Statements of the form 'English x is always a translation of French w' would be possible but it does not follow that no other English words are used to translate w.

11. The humour of member arises from a touch of the archaic--one thinks of the mid-eighteenth century novel by John Cleland, Fanny Hill: memoirs of a woman of pleasure: “...lifting the linen veil that hung between us and his master member of the revels, [he] exhibited one whose eminent size proclaimed...." In the absence of contemporary linguistic commentary, we cannot know how member was received, stylistically speaking, in 1748. It might not have been seen as humorous or euphemistic. There may even have been a neutral style in English at that time.

12. Klimkiewicz notes that the Polish translation contains the same alternations of scientific and coarse vocabulary as the English translation (2012: 250).

\section{REFERENCES}

BAKER, Mona (2000): Towards a methodology for investigating the style of a literary translator. Target 12(2):241-266.

BRANCH, Andrew (2013): La traduction fictive en tant qu'élément érotique dans le roman Elles se rendent pas compte de Boris Vian. In: Pier-Pascale Boulanger, ed. Traduire le texte érotique. Figura. Vol. 32. Montréal: Université du Québec à Montréal, Centre de recherche Figura sur le texte et l'imaginaire, 57-71.

Even-Zohar, Itamar (1990/2000): The position of translated literature within the literary polysystem. In: Lawrence Venuti, ed. The Translation Studies Reader. London: Routledge, 192-197.

GAdET, Françoise (1996): Niveaux de langue et variation intrinsèque. Palimpsestes 10: Niveaux de langue et registres de la traduction, 17-40.

GARDNER, Jeremy (2013): Misused English words and expressions in EU publications. Luxembourg: European Court of Auditors, Secretariat General Translation Directorate. http:// ec.europa.eu/translation/english/guidelines/documents/misused_english_terminology_ eu_publications_en.pdf

Hartlen, Neil (2006): Queer Across the Atlantic: Homo/sexual Representation in the United States and France, 1977-2001. Doctoral dissertation, unpublished. Amherst: University of Massachusetts.

House, Juliane (1997): Translation Quality Assessment: a model revisited. Tübingen: Narr.

MalmkJAer, Kirsten (2004): Translational stylistics: Dulcken's translations of Hans Christian Andersen. Translation and Literature 13(1):13-24.

McLintock, Barbara (2013): Who translated the Civil Code of Québec? Circuit 121. http://www. circuitmagazine.org/who-translated-the-civil-code-of-quebec

Mitchell, Kaye (2012): Raunch versus prude: contemporary sex blogs and erotic memoirs by women. Psychology \& Sexuality 3(1):12-25.

Mossop, Brian (2007): The translator's intervention through voice selection. In: Jeremy MuNDAY, ed. Translation as Intervention. London: Continuum, 18-37.

Mossop, Brian (forthcoming): Judging a translation by its cover. The Translator. 
Munday, Jeremy (2008): Style and Ideology in Translation: Latin American Writing in English. New York: Routledge.

ORnston, Darius (1985): Freud's conception is different from Strachey's. Journal of the American Psychoanalytical Association 33(2):379-412.

Penrod, Lynn (2005): Literal and/or free translation of the erotic: the case of La Vie sexuelle de Catherine M. Génesis Revista cientifica do ISAI 5:100-109.

RADHAKRISHNAN, Rajagoplan (2005): Notes on 'Translatability in an Uneven World.' Translation Today 2(2):12-24.

Rao, Sathya and Klimkiewicz, Aurelia (2012): Les défis de la traduction de La vie sexuelle de Catherine M. en anglais et en polonais. Neohelicon 39:235-254.

Reynolds, Siân (2004): Review of: Christopher Prendergast, ed. (2002): Marcel Proust: In Search of Lost Time. London: Allen Lane, The Penguin Press, 3,300 p. Translation and Literature 13(1):124-130.

Santaemilia, José (2009): La vie sexuelle de Catherine M.: a journey through 'woman,' 'sexual language' and 'translation.' Sendebar 20:123-141.

Vinay, Jean-Paul and Darbelnet, Jean (1958). Stylistique comparée du français et de l'anglais. Montréal: Beauchemin.

VAN Hoof, Henri (2003): Les mots de la chose: dictionnaire de l'érotisme, français et anglais. Paris: Pauvert.

\section{APPENDIX 1}

An expression frequently used by translators to discuss register is of some terminological interest. English translators who work from French frequently speak of 'level of language,' an expression that probably originated as a literal translation of French niveau de langue. (English-speaking translators calqued several translational terms from French in the mid$20^{\text {th }}$ century, such as 'false friend' and 'revision' in its French sense 'review.') Niveau de langue is recorded in the Robert dictionary from the mid-twentieth century on. Vinay and Darbelnet (1958: 11, 33-35) used it in the late 1950s to refer to variations in language that depend on the extent of a speaker/writer's education. Nowadays, the term more often refers to variation with situation of use rather than variation with speaker. Translators will say that English freebie conveys the meaning of French gratuite but not at the same level of language; it is too informal. Gadet (1996) calls into question the very validity of the concepts of 'level' and 'register,' claiming that it is quite normal for people to shift registers even when there is no change in the external situation. Whatever the merits of her argument with respect to sociolinguistic theory, it is irrelevant to the concerns of this paper since translators do in fact work with these concepts, sometimes quite consciously, sometimes less so.

'Level of language' implies a vertical scale. The translator of Tricks seems to invoke such a scale when he speaks of "a middle language somewhere between the smell of the sewer and the smell of the lamp" (1982: 251). There is an underlying image here of a ladder with rungs: the ladder has a bottom rung (the sewer), a top rung (the lamp), and a 'middle' rung. One is at first reminded of the social ladder, 'low' language being associated with 'low' social class, but this way of viewing levels of language is now dated. Members of all social classes use both coarse and euphemistic language. Similarly, technical language is used just as much by plumbers as it is by doctors, when they are at work. And everyone varies the formality of their speech depending on who they are addressing and under what circumstances.

Another problem with Howard's image of a ladder is that it is not at all clear why what he calls the 'clinical' style (presumably what I have called the medical/biological style) should be at the top rung. Why not the euphemistic style, it being the 'least coarse'? There would seem to be no grounds for deciding this matter, though the problem could be resolved by envisioning the scale as horizontal rather than vertical. Of course, that would also eliminate the notion of 'levels,' which assumes a vertical scale. If one wanted a better metaphor than a ladder for talking about a set of styles, one might envisage them as a hon- 
eycomb; this would eliminate any suggestion of an inherent order in the styles.

A more important difficulty with the image of a ladder, or even a horizontal scale, is that in the case of sex writing, there is no 'substance' (like formality or technicality) of which one can identify various degrees. Even if one invented such a substance (perhaps degrees of 'frankness,' or 'niceness'!), it is unclear how the five styles I mentioned would be positioned on the scale. On a horizontal scale, would 'religious/archaic' be at one end or somewhere in the middle, and would it be next to 'legal/learned' or separated from it by some other style?

Extending the notion of levels beyond formality and technicality does not appear to be useful.

Finally, we may wonder whether the ladders of two languages are comparable for purposes of translation. Each language will have its own ladder of levels, and in separate analysis of each language, one might assign the label 'coarse' to a rung on one of the ladders and the label 'coarse' to a rung on the other ladder. But those two rungs may not function in the same way in their respective cultures. This may or may not pose a problem for translators, depending on how they see the task. If the task is to convey the effect of the source text, then there will be an insoluble problem. If however the task is to create a text that 'works' in the target culture, and in particular, one that satisfies the party paying for the translation (in the two works under discussion here, a publishing house), then comparability of levels may not matter very much. The important thing will be the selection from available target-language styles, just as in original writing in that language; the sourcelanguage styles will not be of interest for themselves.

To sum up on style levels, it does seem best to abandon the notion of a 'middle' style and instead adopt the notion of a 'neutral' style, defined negatively as that style which is not any of the others.

\section{APPENDIX 2}

Hunter's translation of the Millet book has been criticized both in the Translation Studies literature (Penrod 2005: 105-6) and in literary reviews: Jenny Diski reproduces a few sentences from the translation and comments that "there is a problem here in that the translation indicates very little of the clarity and style that Millet's prose was praised for in the original. Either it was done in a great hurry, or the translator has only a passing acquaintance with colloquial English" (London Review of Books 24(14), 28-9, 2002).

My own criticism would begin with the English title, assuming it was chosen by the translator rather than the publisher: why sexual life instead of sex life? Sexual seems to be a careless copying of the French word form. Sexual life suggests that the author's life is characterized above all by its sexual aspect. The semantic relationship between the two words is the one found in difficult life or long life rather than the one found in home life or work life. Millet was certainly not suggesting that her life had mostly consisted of having a lot of sex!

Very often Hunter seems to have a tin ear. Her translation of Même lorsque la queue est déjà bien raide, je ne la prends pas dans le con sans lui avoir consacré ne serait-ce qu'une brève fellation (Millet: 105) is Even when his dick has really stiffened, I don't take it in my cunt before devoting just the briefest fellatio to it. The collocation devote...fellatio to is nonsensical, unidiomatic and incommensurable in style with dick and cunt whereas there is no parallel incommensurability in the French. In the phrase consacrer...une fellation, the verb has no religious connotation (so there is no need for devote); it is semantically empty, with the burden of meaning falling on fellation. Why did Hunter not simply write ...before sucking it, even if just for a moment?

I could not detect any principle at work in Hunter's style choices. Her odd word choices divert the reader's attention from the narrative and from the author's literary agenda. 